\title{
Organelle pathology in ulcerative and Crohn's colitis with special reference to the lysosomal alterations
}

\author{
C O`MORAIN, P SMETHURST, A J LEVI, AND T J PETERS \\ From the Divisions of Clinical Sciences and Clinical Cell Biology, MRC Clinical Research Centre, Harrow, \\ Middlesex
}

SUMMARY Rectal biopsy specimens from control subjects, patients with either active or quiescent ulcerative colitis, and patients with Crohn's colitis were examined histologically and assayed for marker enzymes associated with tissue organelles. They were catalase (peroxisome); neutral $\alpha$-glucosidase (endoplasmic reticulum); alkaline phosphatase (plasma membrane); malate dehydrogenase (mitochondria); lactate dehydrogenase (cytosol). There was no significant change in these enzyme activities in patient samples compared with controls. Activities of three acid hydrolases (lysosomal enzymes), $\beta$-glucuronidase, acid phosphatase, and N-acetyl- $\beta$ glucosaminidase, were also assayed in the biopsy samples. Decreased activities of all three enzymes were noted in ulcerative colitis, particularly in active disease. Normal values were obtained in Crohn's colitis. Measurement of lysosomal integrity by assays of latent $\mathrm{N}$-acetyl- $\beta$ glucosaminidase activity revealed similar results in control and colitic subjects. It is suggested that the lysosomal changes reflect a specific tissue release of enzyme and may be implicated in the pathogenesis of the tissue damage.

The aetiology and pathogenesis of ulcerative colitis remains unknown. Many theories have been proposed including infective, autoimmune, dietary, and psychosomatic. The characteristic histological picture is an acute inflammatory response but the pathogenesis of the epithelial cell damage remains unsolved. Lysosomes have been implicated in the pathogenesis of ulcerative colitis, both in $\operatorname{man}^{1}$ and the experimental animal. ${ }^{2}$ In this study the organelle pathology of ulcerative colitis was studied by measuring marker enzyme activities of organelles in rectal mucosa. a recently introduced approach to the study of tissue pathology. ${ }^{3}$ Patients with Crohn's colitis were used as 'disease controls' to determine the specificity of any alteration observed.

\section{Methods}

PATIENTS

A group of 103 patients in whom rectal mucosal histology was required for diagnostic follow up purposes was studied. Two biopsies were taken at sigmoidoscopy from adjacent areas of the rectum

Address for correspondence: Professor T J Peters. Division of Clinical Cell Biology. Clinical Research Centre. Watford Road. Harrow. Middlesex.

Received for publication 29 July 1983 below the peritoneal reflection. Biopsies were classified on histological grounds into four groups: 22 patients with active ulcerative colitis with typical histological findings of an acute inflammatory response of the mucosa and submucosa, goblet cell depletion, glandular distortion, and crypt abscesses: 27 patients with quiescent ulcerative colitis with resolution of the acute inflammatory response and restoration of the goblet cell population, but with distorted and atrophic glandular architecture; 25 patients with Crohn's colitis with compatible clinical and radiological features -10 of these patients had non-caseating granulomas and one had fissuring ulceration, characteristic of Crohn's disease, the remainder had either focal or transmucosal inflammation with lymphocyte aggregates and preservation of goblet cells; control biopsies, which were histologically normal, from 29 patients attending the gastroenterology clinic for investigation of nonspecific symptoms in whom no significant pathology was subsequently found and whose rectal biopsies were histologically normal. One of the biopsies was placed in formalin for histological examination. The other biopsy was processed for enzyme analysis. This biopsy was placed in $3 \mathrm{ml}$ ice cold sucrose $(0 \cdot 3$ $\mathrm{mol} / \mathrm{l})$ containing disodium EDTA $(1 \mathrm{mmol} / \mathrm{l}) \mathrm{pH}$ 
7.4 and ethanol $(22 \mathrm{mmol} / \mathrm{l})$ (sucrose medium). The biopsy was then finely minced in a Polytron homogeniser (Kinemetica GMBH, Lucerne) for 15 seconds at speed setting 2 and disrupted by 10 strokes of a loose fitting (type A) pestle and 10 of a tight fitting (type B) pestle in a Dounce homogeniser (Kontes Glass Co, Vineland, New Jersey, USA). The homogenate was coded and stored at $-20^{\circ} \mathrm{C}$ for subsequent enzyme analysis.

A further eight biopsies were obtained from patients with active disease and from eight control subjects for determination of latent $\mathrm{N}$-acetyl- $\beta$ glucosaminidase activity. ${ }^{+}$This was determined by assaying the enzyme activity in sucrose with the appropriate buffered substrate with (total activity) and without (free activity) Triton X-100 (100 mg/100 $\mathrm{ml}$ ). The homogenates were prepared in the same way as described above but were not subjected to Polytron homogenisation and each was disrupted with only five strokes of the loose fitting pestle (type A). The activity was measured immediately on obtaining the homogenate. The latent activity was expressed as a percentage from the formula:

$$
\frac{\text { total activity }- \text { free activity }}{\text { total activity }} \times 100
$$

Enzyme activities of the homogenates were determined by microanalytical methods previously described. ${ }^{+}$The results were expressed as milliunits of enzyme activity $/ \mathrm{mg}$ of protein $(\mathrm{mU} / \mathrm{mg}$ protein) in the biopsy homogenate, where 1 unit is equal to 1 $\mu \mathrm{mol}$ of substrate transformed $/ \mathrm{min}$. Statistical analyses were performed using a one way analysis of variance.

\section{Results}

MARKER ENZYME ACTIVITIES

Figs 1 and 2 show the activities of various organelle marker enzymes and of protein in rectal biopsies in the various patient groups.

\section{Catalase (peroxisome)}

There was no significant difference in mean activity in any of the patient groups studied: controls $(25 \cdot 1$ $\mathrm{mU} / \mathrm{mg}$ protein $)$; active ulcerative colitis $(22.6 \mathrm{mU} /$ $\mathrm{mg}$ protein); quiescent ulcerative colitis $(25.7 \mathrm{mU} /$ $\mathrm{mg}$ protein); Crohn's colitis ( $21.2 \mathrm{mU} / \mathrm{mg}$ protein).

\section{Neutral $\alpha$-glucosidase (endoplasmic reticulum)}

There was no significant difference in the mean activity in any of the groups: controls $(0.55 \mathrm{mU} / \mathrm{mg}$ protein); active ulcerative colitis $(0.45 \mathrm{mU} / \mathrm{mg}$ protein); quiescent ulcerative colitis $(0.48 \mathrm{mU} / \mathrm{mg}$ protein); Crohn's colitis $(0.73 \mathrm{mU} / \mathrm{mg}$ protein $)$.

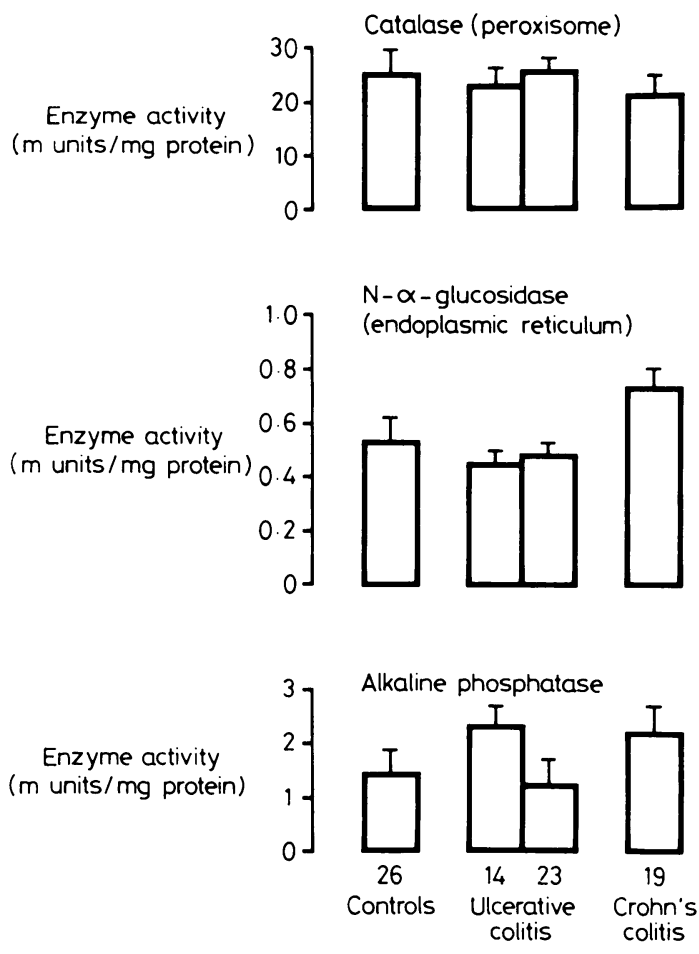

Fig. 1 Enzymic analysis of rectal biopsies. Results show mean $\pm S E$ for indicated number of specimens assaved in duplicate. Left histogram active ulcerative colitis, right histogram, quiescent ulcerative colitis.

Alkaline phosphatase (plasma membrane)

There was no significant difference in the mean alkaline phosphatase concentrations in any of the groups studied: controls $(1.3 \mathrm{mU} / \mathrm{mg}$ protein); active ulcerative colitis $(2.3 \mathrm{mU} / \mathrm{mg}$ protein): quiescent ulcerative colitis $(1.2 \mathrm{mU} / \mathrm{mg}$ protein): Crohn's colitis $(2 \cdot 2 \mathrm{mU} / \mathrm{mg}$ protein $)$.

\section{Malate dehydrogenase (mitochondria)}

There was no significant difference in the activity of this enzyme in the various patient groups: controls ( $930 \mathrm{mU} / \mathrm{mg}$ protein); active ulcerative colitis $(599$ $\mathrm{mU} / \mathrm{mg}$ protein): quiescent ulcerative colitis $(677$ $\mathrm{mU} / \mathrm{mg}$ protein): Crohn's colitis $(807 \mathrm{mU} / \mathrm{mg}$ protein).

\section{Lactate dehydrogenase (cytosol)}

There was no significant difference in the activity of this enzyme in the various groups: controls (74.9 $\mathrm{mU} / \mathrm{mg}$ protein): active ulcerative colitis $(77.9 \mathrm{mU} /$ $\mathrm{mg}$ protein); quiescent ulcerative colitis $(80.8 \mathrm{mU} /$ $\mathrm{mg}$ protein); Crohn's colitis ( $81.8 \mathrm{mU} / \mathrm{mg}$ protein). 

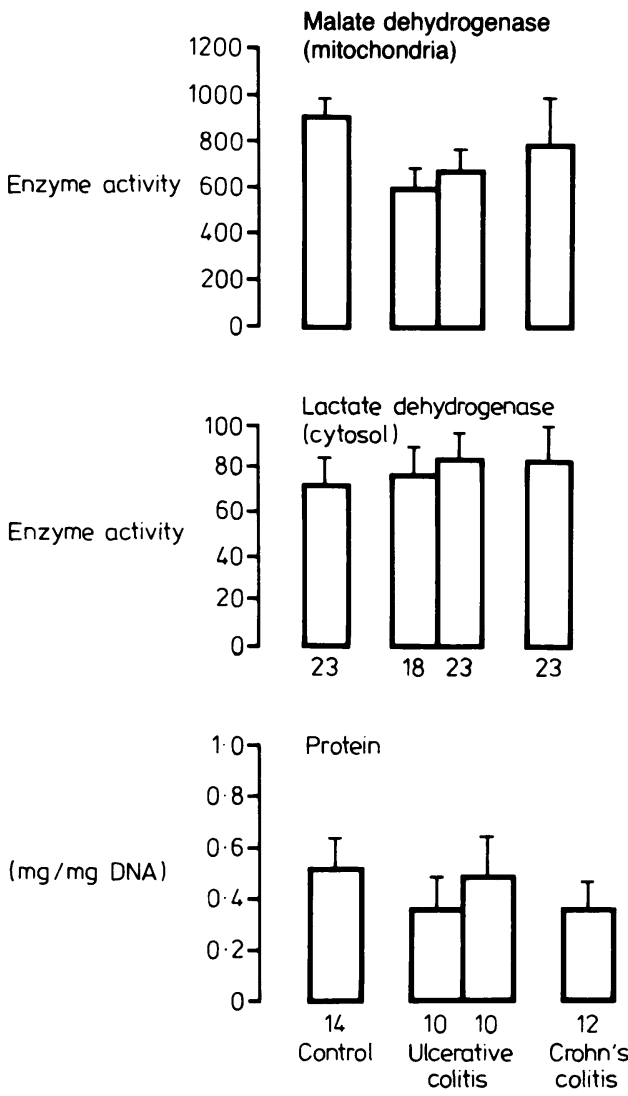

Fig. 2 Enzymic and protein analysis of rectal biopsies. Results show mean $\pm S E$ for indicated number of specimens assaved in duplicate. Left histogram, active ulcerative colitis, right histogram, quiescent ulcerative colitis.

\section{Protein}

Enzyme activities are expressed as $\mathrm{mU} / \mathrm{mg}$ protein. There was no significant change, however, in the protein content expressed/mg DNA - that is per cell, between any of the patient groups.

\section{LYSOSOMAL ENZYME ACTIVITIES}

In contrast with the normal results obtained for the other marker enzymes, the acid hydrolases showed consistent and significant alterations in both acute and quiescent ulcerative colitis (Fig. 3).

\section{$\beta$-Glucuronidase}

The activity was significantly reduced $(0.92 \mathrm{mU} / \mathrm{mg}$ protein) in the active ulcerative colitis group compared with controls $(2.2 \mathrm{mU} / \mathrm{mg}$ protein). Activities in Crohn's colitis patients $(2.3 \mathrm{mU} / \mathrm{mg}$ protein) were also similar to controls. The patients
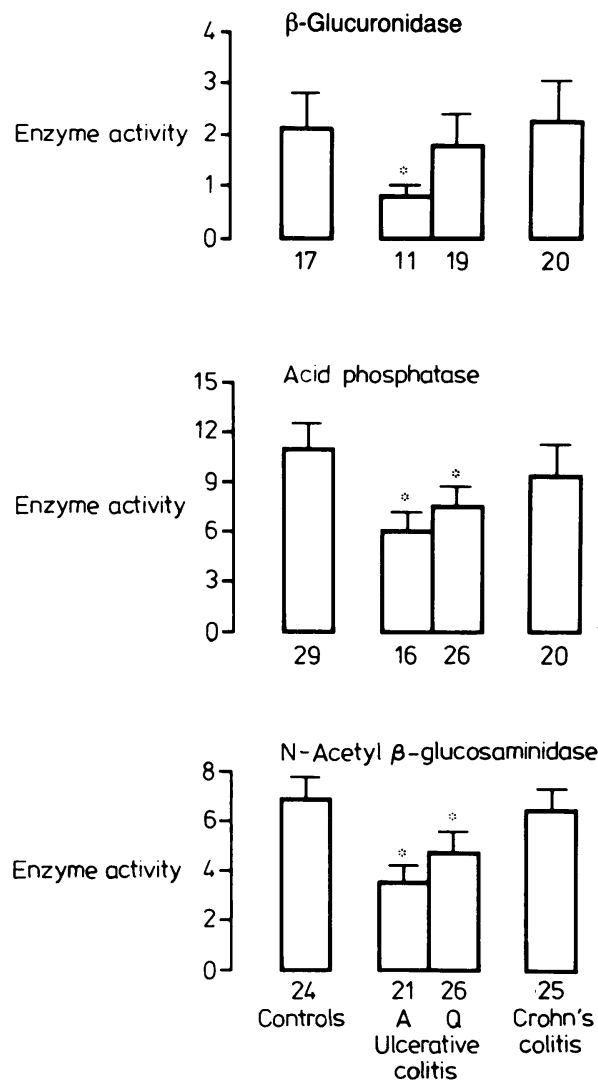

Fig. 3 Assay of lysosomal enzymes in rectal biopsies. Results show mean $\pm S E$ for indicated number of specimens assayed in duplicate. $A=$ active ulcerative colitis; $Q=$ quiescent ulcerative colitis. ${ }^{*} p<0.05$.

with quiescent colitis show a lower activity (1.9 $\mathrm{mU} / \mathrm{mg}$ protein) compared with controls, but the difference does not reach statistical significance.

\section{Acid phosphatase}

The results show a pattern with lower activities in the active $(6 \cdot 1 \mathrm{mU} / \mathrm{mg}$ protein) and quiescent $(7 \cdot 1$ $\mathrm{mU} / \mathrm{mg}$ protein) ulcerative colitis groups compared with the control $(11.0 \mathrm{mU} / \mathrm{mg}$ protein) and Crohn's colitis $(9 \cdot 1 \mathrm{mU} / \mathrm{mg}$ protein) groups.

\section{$N$-Acetyl- $\beta$-glucosaminidase}

The activities of active $(3.6 \mathrm{mU} / \mathrm{mg}$ protein) and quiescent $(4.8 \mathrm{mU} / \mathrm{mg}$ protein) ulcerative colitis groups are significantly lower than the control $(7 \cdot 0$ $\mathrm{mU} / \mathrm{mg}$ protein) and Crohn's colitis $(6.3 \mathrm{mU} / \mathrm{mg}$ protein) groups. 
Assays of $\%$ latent $\mathrm{N}$-acetyl- $\beta$-glucosaminidase showed similar values (mean $\pm \mathrm{SE}$ ) for control $(50 \cdot 4 \pm 5 \cdot 5, n=8)$ and colitic patients $(50 \cdot 4 \pm 6 \cdot 1$, $\mathrm{n}=8)$.

\section{Discussion}

These results show that patients with ulcerative colitis have decreased activity of lysosomal enzymes in their rectal biopsies. The activity of the lysosomal marker enzymes, $\mathrm{N}$-acetyl- $\beta$-glucosaminidase and acid phosphatase, in both active and quiescent colitis, was significantly decreased. $\beta$-Glucuronidase was only significantly reduced in acute colitis. The latent activity of $\mathrm{N}$-acetyl- $\beta$-glucosaminidase was not decreased in active ulcerative colitis indicating that the lysosomes are not more fragile. The low concentrations of lysosomal enzymes could be caused by extracellular discharge, decreased synthesis, increased catabolism, or the presence of inhibitors. Available evidence indicates that acid hydrolase activities are responsible for intracellular digestion of foreign substances as well as intracellular catabolism of native material. ${ }^{5}$ Lysosomal acid hydrolase activities have been implicated pathogenically in several diseases including inflammatory joint disease 6 and systemic lupus erythematosis. ${ }^{7}$ It is suggested that a variety of stimuli including viral endotoxins, antigen-antibody complexes and toxic metabolites rupture lysosomal membranes, liberating acid hydrolase activity throughout the cell, leading to intracellular digestion and ultimately to cell death. Danovitch $e t$ $a l^{1}$ have found decreased concentrations of aryl sulphatases and $\beta$-glucuronidase but, surprisingly, increased concentrations of acid phosphatase in tissue homogenates from patients with ulcerative colitis. They only examined biopsies from four patients, however, which may account for the anomolous results. Kane and Vincenti ${ }^{8}$ also found decreased levels of $\mathrm{N}$-acetyl- $\beta$-glucosaminidase in rectal tissue homogenates from patients with active colitis. They did not, however, differentiate ulcerative from Crohn's colitis.

These findings in ulcerative colitis are specific as they are not observed in Crohn's colitis even though the degree of inflammation may be striking, particularly in comparison to quiescent ulcerative colitis. They suggest that the lysosomal changes relate to epithelial cell alterations and do not only reflect the inflammatory cell reaction. The normal values for the other organelle marker enzymes further emphasises the lysosomal changes. Assays of DNA content of these biopsies ${ }^{9}$ show similar levels in the various patient groups as reflected by constant protein/DNA values and thus similar conclusions are reached if the activities are expressed per $\mathrm{mg}$ of DNA.

Lysosomal changes are observed in patients with coeliac disease before treatment. The intestinal tissue from these patients, however, show increased activities of several lysosomal enzymes together with enhanced lysosomal fragility. ${ }^{10} 11$ The general rule appears to be that accumulation of undegradable material within lysosomes leads to increased levels of several acid hydrolases with enhanced lysosomal fragility. ${ }^{3} 12$ This is clearly not the situation in ulcerative colitis and it is likely that the low enzyme concentrations reflect increased loss.

The other organelle marker enzymes assayed showed no significant differences between controls and the disease groups studied. This is of particular interest when one considers the gross tissue damage which appears both macroscopically and microscopically and attaches more importance to decreased levels of lysosomal enzymes in ulcerative colitis.

There are distinct differences between these two forms of colitis, on epidemiological and histological grounds, and more subtle differences have been detected by immunocytochemical and radioimmunoassay techniques which show vasoactive intestinal peptide nerve hypertrophy and an increased peptide content in Crohn's disease tissue. ${ }^{13} 14$ The inflammatory response in acute ulcerative colitis is much more florid than in Crohn's colitis and this has been confirmed by biochemical assays of neutrophil and lymphocyte markers. ${ }^{9}$ It has been suggested that neutrophils fail to accumulate in sufficient number at a site of inflammation in Crohn's disease ${ }^{1516}$ and that this is important in its pathogenesis.

Clearly further studies are necessary to investigate the role of lysosomal enzymes in the pathogenesis of inflammatory bowel disease. More detailed investigations, possibly with organ culture techniques, of lysosomal enzyme synthesis, extracellular discharge. and degradation should prove interesting.

We are grateful to Dr A Price and Dr G Slavin for the histological reports and to Mrs M Moriarty for secretarial assistance. This work was supported in part by an MRC Project Grant.

\section{References}

1 Danovitch S, Galluci A. Shora W. Colonic mucosal lysosomal enzyme activities in ulcerative colitis. $\mathrm{Am} \mathrm{J}$ Dig Dis 1972; 17: 977-92.

2 Marcus R, Watt J. Seaweeds and ulcerative colitis in laboratory animals. Lancet 1969; 2: 489-90.

3 Peters TJ. Investigation of tissue organelles by a 
combination of analytical subcellular fractionation and enzymic microanalysis: a new approach to pathology. $J$ Clin Pathol 1981: 34: 1-12.

4 Peters TJ. Analytical subcellular fractionation of jejunal biopsies specimens, methodology and characterisation of the organelles in norml tissue. Clin Sci Mol Med 1976: 51: 557-74.

5 De Duve C. Wattiaux R. Function of lysosomes. Ann Rev Physiol 1966; 28: 435-92.

6 Weissman. Lysosomal mechanisms of tissue injury in arthritis. $N$ Engl J Med 1972; 286: 141-2.

7 Weissman. The role of lysosomes in inflammation and disease. Ann Rev Med 1967; 18: 97-112.

8 Kane SP. Vincenti AC. Mucosal enzymes in human inflammatory bowel disease with reference to neutrophil granulocytes as mediators of tissue injury. Clin Sci 1979: 57: 295-303.

9 O'Morain C. Smethurst P. Levi AJ, Peters TJ. Biochemical analysis of enzymic markers of inflammation in rectal biopsies from patients with ulcerative colitis and Crohn's disease. J Clin Pathol 1983; 36: 1312-6.

10 Peters TJ, Heath JR, Wansbrough-Jones MH, Doe WF. Enzyme activities and properties of lysosomes and brush borders in jejunal biopsies from control subjects and patients with coeliac disease. Clin Sci Mol Med 1975: 48: 259-67.

11 Peters TJ, Jones PE, Jenkins WJ, Wells G. Analytical subcellular fractionation of jejunal biopsy specimens. enzyme activities, organelle pathology and response to corticosteroids in patients with non-responsive coeliac disease. Clin Sci Mol Med 1978; 55: 293-300.

12 Seymour CA. Peters TJ. Organelle pathology in primary and secondary haemochromatosis with special reference to lysosomal changes. Br J Haematol 1978; 40: 239-53.

13 Bishop AE, Polak JM, Bryant MG, Bloom SR, Hamilton S. Abnormalities of vasoactive intestinal polypeptide-containing nerves in Crohn's disease. Gastroenterology 1980; 79; 853-60.

14 O`Morain C, Bishop AE, McGregor GP et al. Vasoactive intestinal peptide levels and immunocytochemical studies in rectal biopsies from patients with inflammatory bowel disease. Gut 1984; 25: 57-61.

15 O`Morain C. Segal AW, Walker D, Levi AJ. Abnormalities of neutrophil function do not cause the migration defect in Crohn`s disease. Gut 1981; 22: 817-22.

16 Wandall JH. Binder V. Leucocyte function in Crohn's disease. Gut 1982; 23: 173-80. 